\title{
Introducing Everyday 'Digital Literacy Practices' into the Classroom: An Analysis of Multi-layered Media, Modes and their Affordances
}

\author{
Adele Creer* (i) \\ University College Isle of Man, Isle of Man \{Adele.Creer@ucm.ac.im\} \\ Received on 23 October 2017; revised on 24 January 2018; accepted on 02 March 2018; published on 15 July 2018
}

\begin{abstract}
Integrating digital media into classroom practice requires consideration on many levels, how young people access and engage with digital media at the level of media, mode and genre is complex and may redefine how literacy practices in the classroom are perceived. Young people use digital media in their everyday literacy practices and a failure to embrace new technologies in the classroom may lead to a disjuncture between their everyday and college-assessed literacy practices.

Following an analysis of communicative interactions that looked at multi-layered media, modes and their affordances, this paper offers insights from recent research. It looks carefully at the congruence and incongruences that exists between the two literacy practices with the aim to offer rich insights into meaning making in what are comparatively new, digital literacy practices.

A major conclusion is that some assessment tasks do have congruence with young people's everyday literacy practices but at times they either do not take account of the students 'funds of knowledge' (Moll et al.,1992) to the full which is likely to cause confusion and possible under performance.
\end{abstract}

KEYWORDS: DIGITAL LITERACY PRACTICES, MULTIMODAL, MEDIA, MODE, EVERYDAY LITERACY PRACTICES

\section{INTRODUCTION}

This paper focuses on introducing digital literacy practices into the classroom to establish the effectiveness of the media, its encompassing modes and genre/ types of activity. It builds upon a previously written short blog entry that was published by the Association for Learning Technology (Creer, 2016), where I briefly discussed introducing Twitter into the classroom.

The rationale for my research was the underlying belief that educational policy making by the government and educational bodies should be informed by research evidence to bring about changes in education. By exploring young people's literacy practices, my study contributes to informing debates regarding a perceived incongruence between the everyday literacy practices and college-assessed literacy practices of young people. Conse-

*To whom correspondence should be addressed:

University College Isle of Man

Homefield Rd, Douglas

Isle of Man, IM2 6RD quently, this paper adds to debates around a disjuncture between everyday and college-assessed literacy practices as I build on an argument that college assessed tasks do not take into consideration the differences between the two practices at levels of media and mode (Creer, 2017).

Digital literacy practices, is a comparatively new area of study and one that is constantly changing due to fast developments within technology. In a recent practitioner- research study in a Computing department, I explored the literacy practices of students studying for a Diploma in Information Technology (IT). The study involved examining similarities between their everyday and college-assessed literacy practices and the texts they produced. What became clear was that digital literacy practices were more common in the students' literacy practices than I had anticipated and the majority of texts they produced were digital in both their everyday and college-assessed literacy practices. In this paper, I agree with Bull et al. (2016) that 'many things need to change [...] including how current technologies are used and introduced'(p.117) and I argue introducing digital media into the classroom needs to be carefully considered at a micro-level, so that it may have a positive pedagogical impact.

Working inside the boundaries of the New Literacies Study (NLS) framework, I have taken a social semiotic approach and this requires literacy to be viewed as social practice. In addition, a multimodal approach was taken to understanding digital texts produced as instances of literacy practices. English's (2011) definition of a text was adopted so that an understanding of texts to be 'things that are produced with the intention of communicating meaning' (p.68) could be built upon. This useful definition links with ideas within social semiotics and particularly with Halliday's (1978) three dimensional framework of metafunctions, some aspects of which have been used to analyse young people's texts and explore their meaning and are presented in this paper.

To clarify, by 'digital literacy practices', in broad terms I mean what people do where and how, when using digital media. To expand on this I drew on Lea and Jones' (2011) definition as they use the term digital literacies as: 'a heuristic, a lens with which to examine what students do, in the tradition of literacies research' (p.381). These definitions enable a departure from looking at digital literacy being skills that can be taught to students to taking an 
approach that looks at literacy as social practice.

In this paper, I present findings from a recent study that explored the everyday literacy practices and college-assessed literacy practices which on one level revealed congruence however, at a micro-level disjuncture between the two practices was revealed. Although a focus is given to the introduction of the social media site, Twitter into the classroom for assessment, a wider consideration is given to an analysis of multi-layered media, modes and their affordances to offer rich insights into meaning-making in what are comparatively new, digital literacy practices.

\section{METHODS}

To explore young people's everyday and college-assessed literacy practices, I have found the notion of a 'case study design' useful as an organising methodology in my empirical study, as this involved initially working with 24 students and over three years focusing in detail on four participants. Simons (2009) defines a case study approach as 'an in-depth exploration [...] in a 'real life' context. It is research-based, inclusive of different methods and is evidence-led' (p.21). Simons' (2009) definition is useful in this study as it sets the boundaries of what this methodological approach involves. In the first year of my study, I collected data from 24 participants and created 24 case studies, that is one case study per participant. Throughout the three years some cases became more detailed than others as the data collection continued and the number of students participating decreased (See Table 1). Employing this design has enabled me to perform an in-depth study 'probing beneath the surface of phenomena' (Cohen et al., 2011, p.296) and collate and analyse data to reveal findings at a micro level of mode during a longitudinal study.

Using this approach in my study meant I was able to collect data from interviews, discussions, text collection activities, and photographs. My research design was iterative in terms of collecting and analysing the data, exploring the questions and then repeating the process in order to be able to explore the main research questions in depth. For example, photographs were analysed and interviews conducted to ascertain what young people do where, when and how, repeating the same method of analysis for each participant. In addition, texts were analysed to ascertain what media resources young people used in their practice and the method of analysis involved looking for instances of analytical categories (discussed below in Section 3.2).

This research design is similar to Ivanič et al.'s (2007) as they used 32 case studies to "point to general understandings about how literacies can act as resources for learning' (p.707). A second similarity was that Ivanič et al. (2007) developed case studies from data collected from many research activities for example, materials the participating students used in the classroom and in their everyday literacy practices, such as clocks and photographs.

Table 1. Stages of Research: Explore, Collect data and Analyse

\begin{tabular}{|c|c|c|}
\hline Year One & Year Two & Year Three \\
\hline $\begin{array}{l}\text { Emphasis on: } \\
\text { Exploring literacy } \\
\text { practices and texts }\end{array}$ & $\begin{array}{l}\text { Emphasis on: } \\
\text { Exploring } \\
\text { multimodal texts }\end{array}$ & $\begin{array}{l}\text { Emphasis on: } \\
\text { Exploring literacy } \\
\text { practices }\end{array}$ \\
\hline $\begin{array}{l}24 \text { participants: } \\
10 \text { students studying } \\
\text { BTEC Level } 2 \\
14 \text { students studying } \\
\text { BTEC Level } 3\end{array}$ & $\begin{array}{l}10 \text { participants: } \\
\text { Students from the } \\
\text { group of } 24 \text { who } \\
\text { participated in year } \\
\text { one. }\end{array}$ & $\begin{array}{l}4 \text { participants: } \\
\text { Students from the } \\
\text { group of } 10 \text { who } \\
\text { participated in year } \\
\text { two. }\end{array}$ \\
\hline
\end{tabular}

\begin{tabular}{|c|c|c|}
\hline $\begin{array}{l}\text { Data collected: } \\
\text { Clock activity, } \\
\text { document text } \\
\text { activity and group } \\
\text { discussions. } \\
\text { BTEC assignment } \\
\text { work and Functional } \\
\text { English skills exam } \\
\text { practice papers. }\end{array}$ & $\begin{array}{l}\text { Data collected: } \\
\text { Educational } \\
\text { background } \\
\text { individual } \\
\text { discussions. }\end{array}$ & $\begin{array}{l}\text { Data collected: } \\
\text { Responses to the } \\
\text { photograph activity, } \\
\text { literacy mapping } \\
\text { activity and } \\
\text { individual inter- } \\
\text { views. }\end{array}$ \\
\hline $\begin{array}{l}\text { Focus on: } \\
\text { A broad exploration } \\
\text { and analysis of } \\
\text { practices and texts. } \\
\text { Preliminary findings } \\
\text { of two participants, } \\
\text { Jess and Dean. }\end{array}$ & $\begin{array}{l}\text { Focus on: } \\
\text { Detailed multimodal } \\
\text { analysis of texts: } \\
\text { Design of a } \\
\text { multimodal grid used } \\
\text { to transcribe texts. } \\
\text { Design of an } \\
\text { analytical framework } \\
\text { used to analyse texts. }\end{array}$ & $\begin{array}{l}\text { Focus on: } \\
\text { Detailed analysis of } \\
\text { practices: } \\
\text { Transcription and } \\
\text { analysis of inter- } \\
\text { views and analysis } \\
\text { of photographs using } \\
\text { frameworks. }\end{array}$ \\
\hline
\end{tabular}

In addition to following a case study design, I followed ethnographic perspectives (Green and Bloome, 1997) as it allowed an exploration of my own teaching context along with a consideration of emic and etic perspectives (see Creer (2017) for further discussion). My decision to draw on ethnographic perspectives and a case study design is substantiated by both Clyde Mitchell (1984) and Roberts (2006). Clyde Mitchell (1984) states 'Case studies are the detailed presentation of ethnographic data relating to some sequence of events' (p. 237) and Roberts (2006) in her discussion of qualitative research, discusses case studies that 'sit comfortably' with ethnographic perspective (p.9). A major strength of the case study approach is that multiple perspectives can be documented and 'explain how and why things happened' (Simons, 2009, p. 23). A limitation however is that the case study is 'locked in time whilst the people in it have moved on' (p. 24). Nevertheless, Simons (2009) argues it is possible using a case study approach to 'present a rich portrayal of a single setting to inform practice, establish the value of the case and/ or add knowledge of a specific topic' (p. 24).

\section{RESULTS}

\subsection{Everyday and college-assessed literacy practices of young people}

In my empirical study, a particular finding was that the majority of literacy practices young people engaged in were digitally mediated for example, Facebook, instant text messages, emails, notes, Twitter, Web 2.0 practices and producing texts using desktop publishing software. However some literacy practices were print-based for example, books, timetables, newspapers, advertisements, worksheets and exam practice papers. At the start of my analysis I used a framework adapted from Pardoe and Ivanič, 2007 and added a further dimension to enable Halliday's (1978) metafunctions to be drawn upon. This addition meant the social and cultural context of the digital literacy practices could be revealed in terms of what young people were reading and writing, why they were reading and writing and with whom they communicated. Initially, I found the way in which the participants engaged with the digital and print- based media was similar in their everyday literacy practices compared with their college-assessed literacy practices; this seemed to mirror their own perspectives that what they did was 'the same'. However whilst there appeared some consistencies in the characteristics of their 
literacy practices in the two domains there were also inconsistencies regarding formality and purpose.

From a microanalysis of texts, my findings show that young people use media/ text types, modes and genre/types of activity in their everyday literacy practices differently to how they use the affordances of the media and modes in their college-assessed literacy practices. The notion of a gap between what happens in everyday practices and in educational institutions may be addressed and a greater convergence between everyday and college-assessed literacy practices can be considered, potentially serving to motivate and help students achieve in their FE studies. Engaging in literacy practices that are relevant to everyday life bring together the concepts of 'funds of knowledge' and different forms of 'capital' (Bourdieu, 1991) which in turn addressed Wolf's (2011) call for improvements to be made in the literacy and numeracy provision in FE to prepare young people to enter the labour market.

Gaining the students' perceptions of their literacy practices was a particular aim in my study and this was achieved through discussions and interviews. What became apparent in my analysis was that most young people see their literacy practices while at college and outside college as similar. In an interview, a student stated that he sees everything that he did at college as generally similar to what he does at home apart from the reading for leisure and added 'I don't read at college, not book wise (a novel) more online, like the news'. It is interesting to consider this perception as, following a microanalysis of the texts he engaged with, there emerged some incongruence between what he does at home and at college at the level of media, mode and genre of text. The inconsistency I noted in the explanation of what the student perceived to be the same and what he did differently in the two domains may be explained in terms of the purpose for which he engaged with literacy practices both at home and college. For example whilst he stated he writes on the computer in the same way at home and at college he also stated he preferred to use Facebook to socialise at home rather than at college. The overarching purposes of reading and writing to search for information, to get things done and to communicate appear to happen in both domains; the difference is that in addition, at home he read particular types of digital media for leisure, such as Facebook.

\subsection{Texts young people produce}

A prominent finding from my analysis of the texts young people produced was that when young people engaged with texts in their everyday literacy practices they used a wide range of media, some paper-based but the majority of texts were produced using digital media. The texts they engaged with included booklets, webpages, blogs, videocasts, emails, Facebook pages, instant text messages and Twitter. The modes they employed to design their texts included images, colour, font, space, layout and digitally created writing. "Understanding these modes and their intermodal relationships enabled the complex meaning of the texts to be revealed. Furthermore from the deep exploration of texts, incongruence between their everyday and college-assessed literacy practices emerged at the levels of media/ text type, mode and genre/ type of activity" (Creer, 2017). This finding was achieved by using multimodal transcripts and creating analytic frameworks, for example the table below is a theoretically grounded analytical framework created to consider media and media affordance. The table includes the most relevant analytical categories that were appropriate for my research and documents examples seen within my data set.
Table 2. Analytical framework: Media and media affordance

\begin{tabular}{|c|c|c|}
\hline \multicolumn{3}{|c|}{ Media and media affordance } \\
\hline Media & $\begin{array}{l}\text { Defined in this study } \\
\text { as the means by } \\
\text { which something is } \\
\text { communicated }\end{array}$ & $\begin{array}{l}\text { For example, } \\
\text { Facebook, instant } \\
\text { text message, Twitter, } \\
\text { email, letter, webpage } \\
\text { and blog. }\end{array}$ \\
\hline Media Affordance & $\begin{array}{l}\text { Involves an } \\
\text { exploration of what } \\
\text { the materials/media } \\
\text { used in the construc- } \\
\text { tion of a text allows a } \\
\text { user to do. }\end{array}$ & $\begin{array}{l}\text { For example, paper, } \\
\text { pens or pencils } \\
\text { crayons, potentially } \\
\text { afford the writing of } \\
\text { or drawing of images. } \\
\text { Alternatively, using } \\
\text { an electronic device, } \\
\text { a keyboard and for } \\
\text { example a web } \\
\text { template affords a text } \\
\text { to be produced } \\
\text { digitally on a screen. }\end{array}$ \\
\hline \multicolumn{3}{|c|}{ Analytical categories used to explore the affordances of digital media } \\
\hline Interactivity & $\begin{array}{l}\text { Is an affordance of } \\
\text { digital media such as } \\
\text { Facebook. The screen } \\
\text { allows a user to } \\
\text { engage with the page } \\
\text { (Mills, 2010). }\end{array}$ & $\begin{array}{l}\text { For example, click on } \\
\text { hyperlinks, add } \\
\text { comments, insert } \\
\text { objects and move } \\
\text { objects. }\end{array}$ \\
\hline Dynamic assembly & $\begin{array}{l}\text { Refers to affordance } \\
\text { by a digital device to } \\
\text { allow a user to enter } \\
\text { into a virtual space } \\
\text { and interact with } \\
\text { features (Baldry and } \\
\text { Thibault, 2006). }\end{array}$ & $\begin{array}{l}\text { For example, } \\
\text { webpage interactions } \\
\text { such as a button can } \\
\text { 'link to other times } \\
\text { and places in other } \\
\text { websites' (Baldry and } \\
\text { Thibault, 2006). }\end{array}$ \\
\hline Virtual existence & $\begin{array}{l}\text { Refers to the features } \\
\text { of the digital texts } \\
\text { that allow a relation } \\
\text { with the virtual } \\
\text { environment in which } \\
\text { they are constructed } \\
\text { (Gillen and Merchant, } \\
\text { 2013). }\end{array}$ & $\begin{array}{l}\text { For example, } \\
\text { re-tweets appear } \\
\text { on followers' site } \\
\text { giving them a longer } \\
\text { existence and a wider } \\
\text { dispersion. }\end{array}$ \\
\hline Recontextualisation & $\begin{array}{l}\text { Refers to 'the way } \\
\text { in which texts [...] } \\
\text { always involve the } \\
\text { use and reuse of exis- } \\
\text { ting bits of language/ } \\
\text { texts' (Lillis, 2013, } \\
\text { p.103). }\end{array}$ & $\begin{array}{l}\text { For example, } \\
\text { recontextualisation } \\
\text { happens when Twitter } \\
\text { messages posted } \\
\text { online appear on a } \\
\text { new screen and 'take } \\
\text { on a new appearance' } \\
\text { (Gillen and Merchant, } \\
2013, \text { p.5). }\end{array}$ \\
\hline Permanency & $\begin{array}{l}\text { Accounts for the lon- } \\
\text { gevity of information } \\
\text { and when online how } \\
\text { 'one has little control } \\
\text { over its interpretation } \\
\text { or replication' } \\
\text { (Minocha and Petre, } \\
2009 \text {, p.52). }\end{array}$ & $\begin{array}{l}\text { For example, the } \\
\text { hardware used can } \\
\text { give texts a sense } \\
\text { of permanence that } \\
\text { is it will be there, } \\
\text { available forever and } \\
\text { remain until deleted. }\end{array}$ \\
\hline
\end{tabular}

My findings indicated that students clearly recognised the change that technological developments have brought, for example a student said that his smart phone was 'essentially everything that you used to do with pen and paper'. The digital literacy practices that the participants engaged in have presented very different 
affordances to print-based media. Their digital literacy practices enabled interactivity, flexibility between synchronous and asynchronous messaging, and an engagement with websites to communicate through multiple modes with others in a manner that did not follow traditional print-based conventions for example left to right, top to bottom reading pathways.

The breakdown of modes and multimodal analysis revealed the resources the students used in everyday and college-assessed literacy practices for example their choice of digitally created writing, image, font, colour, space and layout. As a researcher, I found the momentary capture of a text using for example, screen shots and photographs important as I have been able to transcribe and analyse the modes the young people used in detail. Electronic communication can be transient as in Facebook pages, the participants' pages will by now have changed and been updated with new messages and Newsfeeds. This is interesting as the transient and fixed nature of digital texts allowed users to change and update texts however; this also meant that it was not straightforward to return to messages written in the past.

By considering the verbal and visual features an understanding was gained of why and how more than one mode was chosen to create texts, and to communicate with friends. Employing Halliday's (1978) framework allowed an exploration of the meaning within students' texts and I was able to explore the ideational, interpersonal and textual meanings within the texts the young people produced as instances of their literacy practices. The occurrences of these metafunctions noted in the participants' texts revealed that ideationally, in instant text messages, Facebook messages, tweets, comments posted on a blog and a videocast, arrangements, plans, thoughts and questions were observed in these short texts. The use of colour in a blog indicated a similarity with websites used in everyday literacy practices. In a videocast, the animated image was used to express the author's idea of reliability. Interpersonally the short messages conveyed meanings of friendship and relationships and the use of emoticons and an informal register of writing was used to convey these meanings. This was similar in a blog as the comments added a sense of informality to the assessed task and in a videocast, the recording of the students' voices portrayed a similar friendly relaxed message. Textually, within the short messages, repetition of letters were used, demonstrating students' creative use of linguistic resources. In short messages, there was a clear sense of turn taking and messages appeared as lists in chronological order. In a blog and videocast, the modes were not predetermined and turn taking was seen in the comments of a blog and the voice recording in a videocast.

\section{DISCUSSION}

\subsection{Twitter: an example of everyday digital literacy practices}

Twitter is one example of everyday literacy practices that I introduced into the classroom for assessment purposes as it affords virtual micro blogging and connects people in real time. Users can send tweets, which are single messages of 140 characters or less to keep others up to date and messages can be sent forward to others by using the 're-tweet' facility. This has constraints as the space and the number of characters available limits the length of the message. Through their concept of 'virtual existence' Gi- llen and Merchant's (2012) propose a way of understanding the relation between features of the digital texts and the environment (virtual and real) in which tweets are assembled. Tweets can be posted by keying in 'letters and spaces' to 'constitute our own utterance' (p.5). The tweets then take an 'appearance on the screen', are 'digitalised' and have a 'virtual existence' (p.5).

On the home page a profile picture is displayed adjacent to the name which appears next to each tweet. The inclusion of a photograph makes the messenger instantly recognizable and personalises each site. The photographs are not particularly large or brought to the foreground yet people are easily recognisable, for example, the television personality, Stephen Fry in Figure 1. A photograph or placeholder is always positioned next to a message and allows the viewer to see the person sending the message . This multimodal interaction builds interpersonal relationships and enables friendships to be shaped virtually through the visual and verbal mode, two modes that are paramount in face-to-face communication.

The layout of Twitter is predetermined by the company; lists of contacts and information regarding the number of tweets, people following, followers and what to follow is presented on the left hand side relating to the design feature of being 'Given'. On the right-hand side of the screen, the tweets are listed, relating to what is 'New' (Stenglin, 2009). There is a similarity with the Facebook template as 'Given' information is presented on the left hand side of the screen (the photograph) and 'New' information (tweets) are presented on the right. By limiting the length of tweets, messages are short and succinct, allowing messages to be sent and read quickly and efficiently.

Tweets have a sense of virtual existence (Gillen and Merchant, 2013) which once sent they are re-contextualised and 'take on a new appearance' (Gillen and Merchant, 2013, p.5) enabling longer existence and wider dispersion (Creer, 2016). The durability of the Tweet is explained by Minocha and Petre (2009) who use the term 'permanence' to clarify that once posted digitally a text can be used and re-used for a very long time: They allege the text has 'permanence, and one has little control over its interpretation or replication' (p.52). The texts 'permanency' is partially determined by the network provider and partly determined by the person posting the information (Creer, 2016).

Digital writing is itself multimodal and incorporates for example, shapes, size, colour, and mark- making or inscription (Lillis, 2013, p.23). However, focus can be directed to the verbal aspect of digital writing which is alphabetic but also includes emoticons. Expanding attention to the verbal nature of digital writing permits an appreciation of 'the potential for meaning-making that writing - and indeed speech - offers' (Lillis, 2013, p.26). To enable a key focus on digital writing, I have isolated the digitally created writing mode from the complex multimodal texts. Figure 2 is an extract from a transcript of tweets that a student sent and received on two different days with his friends. In this excerpt, ideationally, Dean and Tony were talking about three things, a discussion of sending college work to a lecturer, the level they had achieved in a particular game and going out. However, they did not discuss in this extract where they were going. In Dean's fourth message some words had been abbreviated for brevity and speed, for example 'mw2', my way too. The length of the tweet had been constrained by the web-based template, thus brevity had been imposed. Dean's tweet 'I'm already 14 I think :)' was related to a level of a game and chronologically later the game 'Halo' was mentioned, implying the game it referred to. 


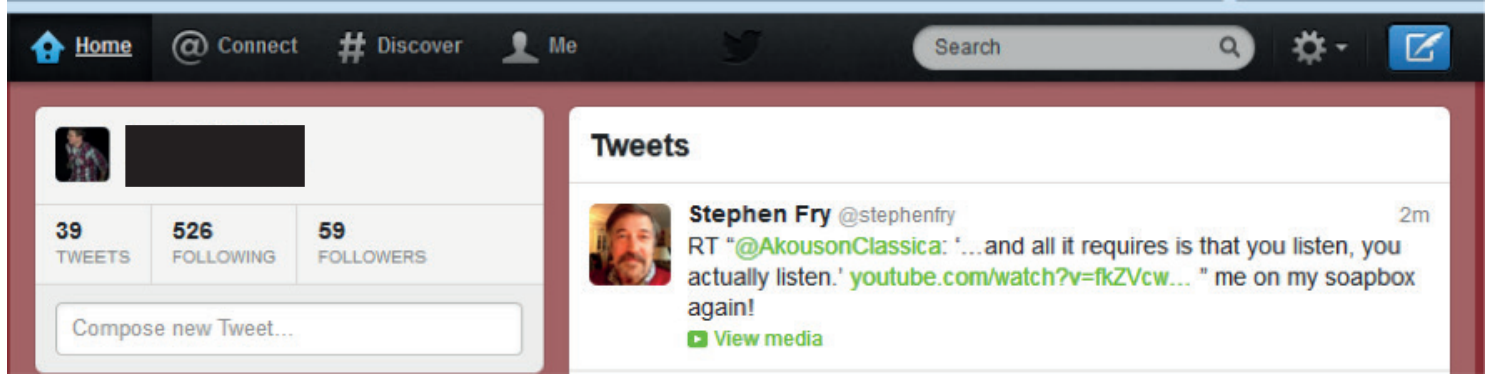

Figure 1. Student's Tweet

\begin{tabular}{|c|c|c|c|}
\hline From & To & Date & Digital Writing \\
\hline Dean & & $7 \mathrm{Nov}$ & $\begin{array}{l}\text { They said bring them in tommorow if you can if not you can the } \\
\text { to her via email }\end{array}$ \\
\hline Dean & (a) Chris & $7 \mathrm{Nov}$ & Any chance you can send them posters via email? $\mathrm{X}$ \\
\hline Dean & @Tony & $6 \mathrm{Nov}$ & I am? Well im on mw2 now. Got bored of halo \\
\hline Dean & @Tony & $6 \mathrm{Nov}$ & I'm already 14 I think :) \\
\hline Dean & @Tony & $6 \mathrm{Nov}$ & What level are you at? \\
\hline Dean & & 6 Nov & I am a tank :) What level you at? \\
\hline
\end{tabular}

Figure 2. Transcript of Dean's Twitter Feeds

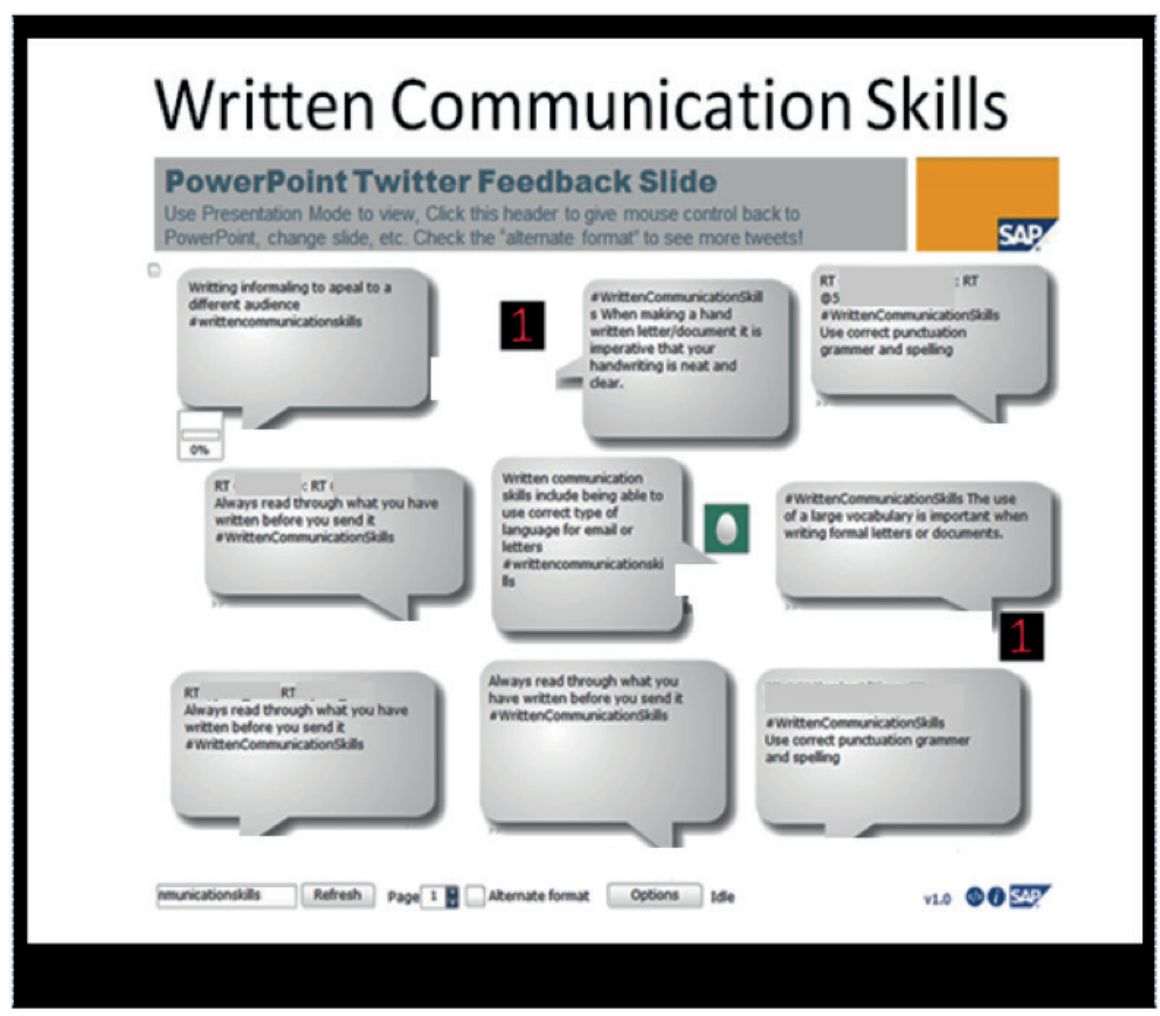

Figure 3. PowerPoint slide with Twitter feeds 


\subsection{Introducing Twitter into the classroom for assessment}

During my study, Twitter was introduced into the classroom through an assessment task. By using Sap Web PowerPoint tools, twitter feeds were incorporated in speech bubbles on a PowerPoint slide and regularly updated (see Figure 3). Hashtags organised the tweets and the Sap Web tool arranged the presentation of the tweets. Refreshing the slides enabled new Tweets to be viewed and this indicated that students were engaging in reading and writing using software to engage in sociocultural, collaborative learning.

\subsection{Congruence between everyday and college- assessed texts}

As previously noted, my study looked at the media and modes students used in their everyday and college-assessed literacy practices with the aim of identifying any congruencies or incongruences between the literacy practices in the two domains. Due to the flexibility within the assignment specification around choice of media for assignment work, I was able to introduce Twitter into the students' assessments. This intervention enabled greater congruence between everyday and college-assessed literacy practices to be created. Nevertheless, this was only one instance of intervention and on the whole, there was typically a high level of incongruence between participants' everyday and college assessed literacy practices in particular in their use of modes, genre and types of activity.

My finding indicated that from a microanalysis of texts, young people use media/ text types, modes and genre/types of activity in their everyday literacy practices differently to how they use the affordances of the media and modes in their college-assessed literacy practices. The affordances of the media and modes used in popular social media forums for example, Facebook were similar to the affordances of the media and modes used in collaborative college-assessed literacy practices such as a blog. However, the register used in digitally created writing, and the provenance of the images they used were incongruent. Recognising this incongruence leads to an understanding of how everyday and college-assessed literacy practices need to complement one another so they can engage young people in education, allowing the 'funds of knowledge' (Moll et. al., 1992) the students bring to the classroom to be built upon.

The digital media the students chose to use in everyday literacy practices and the media they were asked to use to complete college assignments have particular and quite different affordances, for example in the use of templates. Williams (2009) argues that in everyday literacy practices new media technologies offer 'different affordances for each choice made in composing a text, the ability to compose with images, graphics, and video have challenged the traditional print literacy emphasis on linearity in communication' (p.7). Williams' (2009) claim supports my findings that, for example in their literacy practices, the students in my study did not conform to linearity. Their use of hyperlinks and interactive features afforded by the media, enabled them to 'flick' from one webpage to another. When composing texts they included images and videos to communicate meaning alongside digital writing therefore, the combinations of modes needed to be recognised, assessed and credited in the formal curriculum. It appears acknowledging everyday digital literacy practices could increase students' on-line participation and by encouraging points of convergence with college-assessed literacy practices opportunities may arise to guide on-line participation in education.

\subsection{Disjuncture between everyday and college- assessed texts}

A key theme which emerged from my study, is that of disjuncture which I consider to be a detachment and division between everyday and college-assessed literacy practices. This detachment and division may be due to incongruence between young people's everyday and college-assessed literacy practices. There has been a range of empirical research carried out with a focus on disjuncture between school and 'out-of-school' literacies, such as Pahl and Rowsell (2006), Hull and Schultz (2002) and Flewitt (2011).

As previously noted, Ivanič et al.'s (2009) study is the closest to my study in terms of research in FE. The premise for Ivanič et al.'s (2009) major study was that reading and writing do not happen in a 'vacuum' but are situated in the everyday activities of everyday life (p.14). They argue that 'literacies proliferate in response to social change and to the affordances of new technologies' (p.14). From their extensive research, they questioned some of the deep-seated assumptions that inform literacy practices and learning in college, such as 'the widespread assumption that a simple lack of literacy holds back students' (p.16). They started from the proposition that learning is 'textually mediated' (p.19) and focused on the medium of digital and non-digital written communication. Their findings indicate that in the literacy practices for learning and assessment there were disjunctions between the types of literacy used for assessment tasks, such as essay and report writing and the types of literacies used in the workplace, such as keeping logs. This led them to argue that assessments 'should allow students to demonstrate and provide evidence of knowledge, understanding and capability in ways which do not require them to learn special 'assessment literacies' (p.184).

Ivanič et al.'s (2009) study addressed the 'pluralisation of literacy practices and the possibilities they have for pedagogic practices' (p.21). Whilst this is similar to my study, one of the key differences is that Ivanič et al.'s (2009) study 'focuses particularly on written language' (p.19) whereas my study focuses on the multiple modes young people employ to communicate through digital media.

However, there are similarities in terms of some of the themes that they explore. Ivanič et al.'s (2009) most relevant themes for my study include "what students do with reading and writing in their everyday lives' (p.27), 'ways of understanding literacy practices' (p.47) and 'literacies across the college curriculum' (p.69).

Ivanič et al., 2009 argue that assessments 'should allow students to demonstrate and provide evidence of knowledge, understanding and capability in ways which do not require them to learn special 'assessment literacies' (p.184). This informs their argument that academic literacy practices 'do not contribute to the students' knowledge of their subject area and have little bearing on a future world of work' (p.79). Ivanič et al. (2009) found that the types of literacy practices needed for the completion of the college courses were different to the literacy practices students embarked on in everyday life, such as "using their own words instead of those in the source text, and supplying references, bibliographies and appendices' (p.79). This finding was crucial for my study as it recognises a disjuncture between everyday and college-assessed literacy practices and allows a comparison with my findings See Table 3. 
Table 3. Comparison of characteristics of everyday literacy practices with Ivanič et al. (2009)

\begin{tabular}{|c|c|c|c|}
\hline $\begin{array}{l}\text { Characteristic of everyday } \\
\text { literacy practices }\end{array}$ & $\begin{array}{l}\text { Noted in Ivanič et al. } \\
\qquad(2009)\end{array}$ & $\begin{array}{l}\text { Noted in my study } \sqrt{ } \\
\text { Difference in my study } X\end{array}$ & Examples from this study and comments \\
\hline \multirow{5}{*}{ Be purposeful } & \multirow[t]{5}{*}{$\sqrt{ }$} & & Four overarching purposes: \\
\hline & & $\sqrt{ }$ & Searching for information e.g. internet \\
\hline & & $\sqrt{ }$ & Getting things done e.g. shopping lists \\
\hline & & $\sqrt{ }$ & Communicating with others e.g. Facebook \\
\hline & & $\sqrt{ }$ & For pleasure e.g. reading books \\
\hline Have a clear sense of audience & $\sqrt{ }$ & & $\begin{array}{l}\text { Text messages e.g. A student's text message to his } \\
\text { friend used playful language whereas the text mes- } \\
\text { sage sent to his grandmother was more affectionate } \\
\text { and included kisses }\end{array}$ \\
\hline $\begin{array}{l}\text { Shared, interactive and } \\
\text { collaborative }\end{array}$ & $\sqrt{ }$ & $\sqrt{ }$ & $\begin{array}{l}\text { Participation in gaming sites e.g. A student's inte- } \\
\text { ractive engagement with Steam to collaborate with } \\
\text { his friends }\end{array}$ \\
\hline Be learned through participation & $\sqrt{ }$ & $\sqrt{ }$ & $\begin{array}{l}\text { Participation in social media e.g. A student learnt } \\
\text { how to use hashtags through participating in Twitter }\end{array}$ \\
\hline $\begin{array}{l}\text { Be in tune with students' values } \\
\text { and identities }\end{array}$ & $\sqrt{ }$ & $\sqrt{ }$ & $\begin{array}{l}\text { Facebook profiles show how students would like to } \\
\text { be portrayed and what is important to them }\end{array}$ \\
\hline \multirow{2}{*}{$\begin{array}{l}\text { Tend to be non-linear, for exam- } \\
\text { ple, with varied reading paths }\end{array}$} & \multirow[t]{2}{*}{$\sqrt{ }$} & $\sqrt{ }$ & $\begin{array}{l}\text { Different reading paths e.g. A student flicked from } \\
\text { page to page when reading on a screen }\end{array}$ \\
\hline & & $\mathrm{X}$ & $\begin{array}{l}\text { Some activities were linear e.g. A student's prefe- } \\
\text { rence for reading books }\end{array}$ \\
\hline \multirow{2}{*}{$\begin{array}{l}\text { Draw upon a range of media and } \\
\text { multimodal forms of communi- } \\
\text { cation }\end{array}$} & \multirow[t]{2}{*}{$\sqrt{ }$} & $\sqrt{ }$ & All participants used digital and print-based media. \\
\hline & & $\sqrt{ }$ & $\begin{array}{l}\text { A student 's highway code book used a range of } \\
\text { modes e.g. use of digital writing, image, space }\end{array}$ \\
\hline \multirow{2}{*}{ Varied and non-repetitive } & \multirow[t]{2}{*}{$\sqrt{ }$} & $\sqrt{ }$ & $\begin{array}{l}\text { A student looked at the highway code book in print } \\
\text { and digital format. }\end{array}$ \\
\hline & & $\mathrm{X}$ & $\begin{array}{l}\text { Some activities were repetitive e.g. A student liked } \\
\text { to visit the same websites }\end{array}$ \\
\hline \multirow{2}{*}{$\begin{array}{l}\text { Involve meaning making, creativi- } \\
\text { ty and getting things done }\end{array}$} & \multirow[t]{2}{*}{$\sqrt{ }$} & $\sqrt{ }$ & Creative use of modes \\
\hline & & $\sqrt{ }$ & $\begin{array}{l}\text { Getting things done e.g. A student wrote shopping } \\
\text { lists }\end{array}$ \\
\hline \multirow{2}{*}{$\begin{array}{l}\text { Be self-determined in terms of } \\
\text { activity, time and place }\end{array}$} & \multirow[t]{2}{*}{$\sqrt{ }$} & $\sqrt{ }$ & $\begin{array}{l}\text { All participants choose their activities e.g. websites, } \\
\text { forums, reading books and magazines. }\end{array}$ \\
\hline & & $X$ & $\begin{array}{l}\text { Participants chose the time and location at home but } \\
\text { had restrictions at college e.g. internet sites blocked. }\end{array}$ \\
\hline $\begin{array}{l}\text { Involve making value judgements } \\
\text { and choices }\end{array}$ & $\sqrt{ }$ & $\sqrt{ }$ & $\begin{array}{l}\text { A student liked simple layouts and choosing sites } \\
\text { that have information that is easy to find). }\end{array}$ \\
\hline
\end{tabular}

In UK research conducted in Higher Education institutions, Lea and Jones' (2011) findings revealed a 'complex interrelationship between literacies and technologies with the potential to disrupt conventional academic literacy practices' (p.377). Lea and Jones (2011) adopted an 'ethnographic perspective' in their research, which initially involved 45 undergraduates studying across a range of disciplines. They met their participants three or four times at their educational institutions initially in small groups and then individually. They also kept in close contact with the participants through email and text messages, building a database of transcriptions and texts from a range of contexts, including social network sites, journals, individual and group work. This provided them with evidence of 'digital texts and practices, written, visual, multimodal and web-based' (p.382) for their analysis. Their study (as in related research for example, Goodfellow and Lea (2007)) lead them to suggest that literacy needed to be redefined in the university to take into consideration the ways students are accessing and reading digital media for study and 'integrating these into their assessed work' (p.391).

A disjuncture has also been noted by Mills (2010) as she identifies a gap between 'popular adolescent literacies' both digital and non-digital that happen outside school or college and the 'official' literacies that are rooted in education. One popular out-of-school literacy practice that young people participate in is online social 
networking and through this communication interface, Mills (2010) states, words are integrated with images, sounds and texts that include animation, sound and interactivity (p.35). Mills (2010) proposes that Facebook is one example of a social networking site that young people engage in as part of their everyday literacy practices. On this site, they can post and exchange verbal and non-verbal material along with texts, links, animated images and sounds. As part of a large ethnographic study across several schools and classrooms in Australia investigating students' access to multimodal and digital literacy practices, Mills, (2010) carried out interviews with four students aged 11-12 years. She found that "not all youth today are "digital natives" to the same extent, because there are differences in the nature of multimodal and digital practices across social groups' (Mills, 2010, p.37). Mills (2010) argued that teachers should encourage inclusion in what she terms 'new literacy practices'.

\subsection{Everyday literacy practices as resources for learning and assessment}

My analysis of the data revealed a significant finding that the young people in my study brought into the classroom an understanding of the affordances of everyday media and applied this understanding to their academic tasks, as it appears there are noteworthy similarities in terms of the use of software packages, templates, and images used to communicate meaning. Using the analytic tools of transcribing texts and breaking down the texts to reveal the modes, devising and using an analytical framework has enabled me to see things I had not noticed before. For example, my analysis revealed the layout of websites had some similar structure to traditional textbooks, newspapers and magazines giving similarity to what is seen on the screen to paper-based media. The participants' engagement with websites in their everyday literacy practices and the understandings they gained from this provided 'funds of knowledge' (Moll et al., 1992) from which they were able to draw within their college-assessed literacy practices for example, reading and writing on a gaming website helped with creating and writing a blog in their college-assessed literacy practices. This finding contributes to the debates around FE teaching and learning and bringing funds of knowledge (Moll et al., 1992) into the classroom. It supports the view that students' previous experiences have an important influence on their literacy practices in their college-assessed practices. Although my microanalysis of text revealed incongruence between their everyday and college-assessed literacy practices at the level of media/ text type, mode and genre/ type of activity, students were adapting and using what they already knew to achieve the assessment tasks.

Whether producing digital texts as part of their college-assessed literacy practices or as part of their everyday practices, the students' choices and uses of modes for communication were partially determined by the affordances of the pre-determined structures provided by the web-based or computer-based software they used and how these shaped the construction of a screen or paper page. Consequently, introducing Web 2.0 practices increases points of congruence with everyday literacy practices at the level of media, mode and genre.

As previously noted, I have found many overlaps between everyday and college- assessed literacy practices. However, the way in which the young people engaged with media to produce their texts appeared to be significantly incongruent At this point, I need to return to my position as a teacher-researcher to establish the validity of my claims.

The research I undertook forced me to reflect on what was possible and I found that the level of incongruence of college-as- sessed literacy practices of students demanded by the FE college curriculum was dependent on my interpretation of the specifications, as the teacher and through the media I chose for the students to use. Assignment specifications allowed a range of media and modes to be utilised and a range of literacy practices to be employed. For example, this awarding organisation recognised the need to give students the 'opportunity to use IT tools' (Edexcel, 2010, p.25).

College-assessed literacy practices are entrenched in conventions that at times successfully adapt to the use of new media and at times do not. As previously discussed, Ivanič et al. (2009) suggest teachers could embrace everyday literacy practices, find out what their students engage with and bring this into the classroom to make college work more relevant and meaningful (p.183). However, Mavers' (2009) questions how much everyday literacy practices should influence the curriculum. From my findings it became clear that young people's everyday digital literacy practices influence what they do in the classroom when given the opportunity. Their 'funds of knowledge'(Moll et al., 1992), that is the individual knowledge and experience of young people for example the understanding they develop through their engagement with social media, are brought into the classroom and this can help and engage them in formal college-assessed literacy practices.

\section{STUDY LIMITATIONS}

A [...] key challenge is how to link empirical observation with participants' understandings and perspectives as well as with analysts' description and theorisation of both of these'. (Lillis, 2013, p.84)

The findings in this study represent a glimpse of the practices of the students who participated in my study that was situated in a particular time and place. If this study was to be repeated, the findings might have some differences and some resonances, as each 'repetition' would be specific to a situation in both time and place.

Throughout my study, I was aware that my intention was to improve my teaching practice and find ways to engage young people in their college learning. I would not have achieved the same understanding if I had carried out the same research as an outsider. Researching my own context is not without criticism; an outsider would have less reason to prefer one account of literacy practices over another and may interpret the data differently.

There have been difficulties with studying my own context due to my familiarity with the participants and study site, as I have had particular views and opinions about these. I have needed to maintain my role as a teacher, assessing students' learning and achievement and at times this has conflicted with my role as researcher where I needed to observe what the students were doing and look at where, what, why and how the students engaged in diverse literacy practices. Further difficulties arose whilst exploring the everyday practices of young people due to my role as the participants' teacher. A particular concern arose regarding privacy issues. Whilst the participant students were not reluctant to show me their everyday literacy practices, they were selective, and as their teacher, I felt it would be unethical to cross the boundary from the classroom into their everyday life.

\section{CONCLUSION}

At a micro-level, there appeared to be salient differences in the media the participants engaged with, for example in their everyday literacy practices they used social media and instant text messages allowing them to communicate with family and friends 
whereas in their college-assessed literacy practices their use of desktop publishing templates, allowed them to design and author text.

Increasingly, the activities of young people in everyday life are electronically mediated and enabling them to bring these 'funds of knowledge' (Moll et al., 1992) into the classroom has many advantages for their potential grade outcome, and in turn for their future employment and prospects. Martin (2005) recognised in his DigEuLit project that

'Electronic devices and facilities now underpin the practice of most sectors of society and most human activities. Those who can understand and comfortably use e-facilities are significantly empowered and advantaged, in terms of educational success, employment prospects and other aspects of life' (p.1).

By looking in detail at both the literacy practices of young people and the texts they produced, as a teacher, I have found it possible to ascertain what is going to be advantageous to the students for future educational success, employment and various aspects of life. I have built on an argument that "FE institutions, awarding and governing bodies need to recognise the importance of keeping up with the advances of digital literacy in other domains such as everyday life and in the work place and recognise the skills young people need to prepare for future study or employment" (Creer, 2017).

It appears that using digital media can connect their everyday with their college-assessed literacy practices in terms of reading and writing on the screen. If a careful selection of the media, modes and genre used for assessment are made it would allow 'funds of knowledge' (Moll et al., 1992) to be brought into the classroom. This would in turn enable greater congruence between the young people's everyday and college-assessed literacy practices.

Further and continuing research is needed to focus on the digital writing and multimodal aspects of communication to track how young people are adapting to developing technology. The future research work I plan to carry out is to explore ways of conducting a microanalysis of digital texts and track interactivity of digital literacy practices using screen capture software. I am currently developing the use of Laban's notation symbols (Preston, 1963) and the layout schemas within the multimodal transcripts to explore ways of developing transcription methods to track interactivity. By carrying this out, I hope to gain a further understanding of what students do when they are engaged on the internet researching and producing texts for assessment work. This may develop ideas to help practitioners effectively integrate digital literacy practices in the classroom that reflect the literacy practices of today's society, which is increasingly multimodal.

\section{REFERENCES}

Baldry, A. \& Thibault, P. J. (2006). Multimodal Transcription and Text Analysis. London: Equinox.

Bourdieu, P. (1991). Language and Symbolic Power. Cambridge: Polity Press.

Bull, G., Thompson, A.D., Schmidt.-Crawford, D., Garfalo, J., Hodges, C.B., Spector, J. M., Kinshuk. (2016). Evaluating the Impact of Educational Technology. Journal of Digital Learning in Teacher Education, 32(4)117-118. doi: 10.1080/21532974.2016.1217052

Clyde Mitchell, J. (1984). Case studies. In R. F. Ellen (Ed.), Ethnographic Research: A Guide to General Conduct. London: Academic Press Limited.

Cohen, L., Manion, L., \& Morrison, K. (2011). Research Methods in Education. Oxon: Routledge.

Creer, A. (2016). Introducing Twitter into the classroom: a multimodal analysis. Retrieved from https://altc.alt.ac.uk/blog/2016/08/introducing-twitter-into-the-classroom-a-multimodal-analysis/\#gref

Creer, A. (2017) Communicative interactions in everyday and college-assessed digital literacy practices: Transcribing and analysing multimodal texts. Research in Post-Compulsory Education, 22(3), 315-333. doi: $10.1080 / 13596748.2017 .1358510$

Edexcel (2010). BTEC Level 2 Certificate, BTEC Level 2 Extended Certificate and BTEC Level 2 Diploma in Information Technology. Pearson Education Ltd. Retrieved from http://www.edexcel.com/migrationdocuments/BTEC $\% 20$ Firsts\%20from\%202010/BF021880-Firsts-in-Information-Technology-L2spec-for-web-100810.pdf

English, F. (2011). Student Writing and Genre: Reconfiguring Academic Knowledge. London: Bloomsbury.

Flewitt, R. S. (2011). Bringing ethnography to a multimodal investigation of early literacy in a digital age. Qualitative Research Special Issue on Multimodal Ethnography, 11(3), 293-310. doi:10.1177/1468794111399838

Gillen, J., \& Merchant, G. (2013). Contact Calls: Twitter as a Dialogic Social and Linguistic Practice. Language Sciences, 35, 47-58. doi:10.1016/j.langsci.2012.04.015

Goodfellow, R., \& Lea, M.R. (2007). Challenging e-Learning in the University: A Literacies Perspective. Maidenhead: Open University Press.

Green, J., \& Bloome, D. (1997). Ethnography and Ethnographers of and in Education: A Situated Perspective. In J. Flood, S. Brice-Heath, \& D. Lapp (Eds.), Handbook of Research in Teaching Literacy through the Communicative and Visual arts. London: Prentice Hall.

Halliday, M. A. (1978). Language as Social Semiotics: The Social Interpretation of Language and Meaning. London: Edward Arnold.

Hull, G. A., \& Shultz, K. (2002). School's Out: Bridging Out-of School Literacies with Classroom Practice. London: Teachers College Press.

Ivanič, R., Edwards, R., Barton, D., Martin-Jones, M., Fowler, Z., Hughes, B., Mannion, G., Miller, K., Satchwell, C., \& Smith, J. (2009). Improving Learning in College: Rethinking Literacies across the Curriculum. Oxon: Routledge.

Lea, M. R., \& Jones, S. (2011). Digital literacies in higher education: exploring textual and technological practice. Studies in Higher Education, 36(4), 377-393. doi:10.1080/03075071003664021

Lillis, T. (2013). The Sociolinguistics of Writing. Edinburgh: Edinburgh University Press.

Martin, A. (2005). DigEuLit - a European Framework for Digital Literacy: a Progress Report. Journal of eLiteracy, 2, 130-136.

Mavers, D. (2009). Image in the Multimodal Ensemble: Children's Drawing. In C. Jewitt (Ed.), The Routledge Handbook of Multimodal Analysis. Oxon: Routledge.

Mills, K. A. (2010). Shrek Meets Vygotsky: Rethinking Adolescents' Multimodal Literacy Practices in Schools. Journal of Adolescent and Adult Literacy, 54(1), 35-45. doi:10.1598/JAAL.54.1.4

Minocha, S., \& Petre, M. (2012). Handbook of Social Media for Researchers and Supervisors: Digital Technologies for Research Dialogues. Milton Keynes: The Open University.

Moll, L. C., Amanti, C., Neff, D., Gonzalez, N. (1992). Funds of Knowledge for Teaching: Using a Qualitative Approach to Connect Homes and Classrooms. Theory Into Practice, 31(2), 132. doi:10.1080/00405849209543534

Pahl, K., \& Rowsell, J. (2006). Travel notes from the New Literacy Studies: Instances of practice. Clevedon: Multilingual Matters.

Pardoe, S., \& Ivanič, R. (2007). Literacies for Learning in Further Education: Curriculum review using the LfLFE framework. Retrieved from http://www.lancaster. ac.uk/lfffe/publications/pubsdocs/LfLFE\%20Framework\%20from\%20booklet. pdf.

Preston, V. (1963). A Handbook for Modern Educational Dance. Plymouth: Macdonald and Evans.

Simons, H. (2009). Case Study Research in Practice. London: Sage. doi:10.4135/9781446268322

Stenglin, M. (2009). Space and Communication in Exhibitions: Unraveling the Nexus. In JC. ewitt (Ed.), The Routledge Handbook of Multimodal Analysis. Oxon: Routledge.

Roberts, C. (2006). Figures in a landscape: Some methodological issues in adult ESOL research. Linguistics and Education, vol. 17, (pp. 6-23). doi:10.1016/j. linged.2006.08.009

Williams, B. T. (2009). Shimmering Literacies: Popular Culture and Reading and Writing Online. New York: Peter Lang.

Wolf, A. (2011). Review of Vocational Education: The Wolf Report. Retrieved from https://www.gov.uk/government/uploads/system/uploads/attachment_data/ file/180504/DFE-00031-2011.pdf.

How to cite this article: Creer, A. (2018). Introducing Everyday 'Digital Literacy Practices' into the Classroom: an Analysis of Multi-layered Media, Modes and their Affordances. Journal of New Approaches in Educational Research, 7(2), 131-139. doi: 10.7821/naer.2018.7.265 